\title{
Salafist movement and sheikh-ism in the Tunisian democratic transition*
}

\author{
Fabio Merone $^{\mathbf{a}}$ and Francesco Cavatorta ${ }^{\mathbf{b}}$ \\ a) Research Fellow \\ Gerda Henkel Foundation \\ Fabiomerone2@yahoo.it \\ b) School of Law and Government \\ Dublin City University \\ Francesco.cavatorta@dcu.ie
}

\begin{abstract}
The article examines the complexity of Tunisian Salafism in the context of the Tunisian transition to democracy. Building on primary sources and original field work, the article highlights the theoretical and practical divergences that affect the Salafist camp in Tunisia in its struggle to continue a revolutionary project for a sector of disenfranchised youth unwilling to support a process of renewal of political institutions that they perceive as contributing their marginalization. In addition, the article explores the ways in which, paradoxically, the emergence and public presence of Salafism can contribute to the strengthening of democratic debate in the country.
\end{abstract}

Keywords

Salafism; Sheikhism; mouhammishin; Tunisia; democratization

\section{Introduction}

The English-speaking academic literature on Arab politics and society of the last three decades tended to neglect the case of Tunisia. Despite some notable exceptions, including John Entelis, Stephen King, Eva Bellin,

*) The authors are thankful to the two anonymous referees for their comments, which considerably imrpoved the article. The authors are grateful to the Gerda Henkel Foundation for funding this research in the context of the programme 'From over-estimation to underestimation: the trajectory of political Islam in five MENA countries.' 
Laryssa Chomiak, Christopher Alexander, Emma Murphy, and Melani Cammett, Tunisia never featured prominently either as a single case study or in comparative works. The fall of the Ben Ali regime seemed to change that and both the policy-making community and academia focused extensively on Tunisia. The country offers a significant opportunity to understand and explain the causes of the Arab Spring, gauge the possibility of a transition to democracy in an Arab country, highlight the challenges that regime changes entail and examine their implications for regional politics and international security. However, and true to form, the attention on Tunisia faded quite quickly, particularly after the successful October 2011 elections for the Constituent Assembly, as more 'relevant' countries became embroiled in the 'Spring' with Egypt and Syria in particular taking centre stage.

For the majority of scholars and analysts still following Tunisia, the institutional changes and the daily political developments characterizing the transition have become the exclusive focus. We thus have analyses of the 'success' of the Tunisian transition ${ }^{1}$ together with more sober ones highlighting the problems the country faces as it builds a liberal-democratic system. ${ }^{2}$ All this is certainly important and to a certain extent justified by the fact that the first phase of the transition, roughly from January 2011 until October of the same year, saw the rapid institutionalization and the return to open activism of the traditional political families of the country: the liberal left incarnated by Moncef Marzouki, Najib Chebbi and Mohammad Ben Jaafar, the Islamists led by Rachid Ghannouchi and the extreme left with the communists at the forefront. In addition, there has been the re-appropriation of autonomy on the part of the historic trade union, the UGTT. The elections of October 2011 saw the victory of the Islamist Ennahda, which formed a government coalition with the liberal left in order to guarantee a smooth transition to democracy by overseeing the drafting of a new Constitution. Since then, most analyses have focused on how the government performed, on the internal problems the coalition has, on its supposed incompetence, on Ennahda's perceived 'doublespeak' when it comes to its commitment to democracy and secularism and

\footnotetext{
1) Alfred Stepan, "Tunisia's transition and the twin tolerations," Journal of Democracy 23 (2012): 89-103.

2) Paul Aarts, Pieter van Dijke, Iris Kolman, Jort Statema and Ghassan Damman, From Resilience to Revolt. Making sense of the Arab Spring (Amsterdam: University of Amsterdam, 2012): 1-109.
} 
on the return on the scene of those politicians who are still inspired by Bourguibism together with the usual debate on women's rights. ${ }^{3}$ The assassination of the left-wing political leader Chokri Belaid in February 2013 crystallized many of these debates with numerous analyses examining its impact on the nascent institutions. This almost exclusive focus on institutional politics and on how the new political system deals with the social and economic challenges produces however an analytical vacuum with respect to what is occurring in wider society. This shortcoming reproduces to a large extent the analytical mistakes that were made before the Arab Spring occurred when the attention on the state and on high politics generally clouded the way in which society was reacting to the upgrading of authoritarian rule. ${ }^{4}$ In the Tunisian case, important aspects of the transition have only been marginally examined, preventing therefore a clearer understanding of the emergence of phenomena that are labeled 'surprising' when in fact they might not actually be so. For instance, very little has been made of the low turnout for the October 2011 elections when over 45 per cent of citizens could not be bothered turning out for what were considered 'historic' elections. Such low turnout should lead to ask questions about the political and social attitudes of those who did not vote and about the type of socio-political movements that they might feel represented by. It should also lead to questions about the way in which they might engage socially, if at all, and what the consequences for the transition this might have. The advanced age of the leadership across the political spectrum is a second element that should lead to questions about the role of the younger generation, the one that was at the forefront of the Jasmine Revolution. Where has the youth gone? What kind of social and political activism, if any, draws young Tunisians today in the midst of a process of reconstruction of society and its institutions? A final important element is the middle-class nature of the current process of political democratic institutionalization whereby the poorer strata of the population are barely involved in the construction of the new state.

3) On Ennahda and the transition see Sarah Feuer, "Islam and Democracy in Practice: Tunisia's Ennahda Nine Months In," Middle East Brief, Crown Center for Middle East Studies, Brandeis University 66 (2012): 1-8. On the challenges facing the Tunisian economy see Nader Habibi, "The Economic Agendas and Expected Policies of Islamists in Egypt and Tunisia," Middle East Brief, Crown Center for Middle East Studies, Brandeis University 67 (2012): 1-8.

4) Francesco Cavatorta and Rikke Hostrup Haugbølle, "The end of authoritarian rule and the mythology of Tunisia under Ben Ali," Mediterranean Politics 17 (2012): 179-195. 
Those who are economically marginalized and more generally disenfranchised do not feature much and their demands are dismissed in the name of economic realism with such dismissal coming from the vast majority of political actors, including Ennahda. However these socio-economic and political instances have to eventually find a home, particularly because there is a high degree of pluralism today in the country which permits all sorts of political and social movements to organize and be active. This does not mean that poverty leads inevitably to political radicalization, but it provides a fertile terrain for a religious activism that does not promise the attainment of material wealth, but offers a righteous path to life that becomes attractive when there is little else to strive for in expectation.

The rise of Salafism in the aftermath of the transition does not answer these questions directly, but provides an example of the many complex and unexpected social phenomena that 'explode' on the public scene when the previous political order disappears.

With this in mind, it is hardly surprising that the emergence of Salafism came as a shock to many Tunisians and to the international community and that a significant degree of political and mediatic alarmism has characterized the few analyses of the phenomenon. ${ }^{5}$ Such analyses are usually linked to the threat that Salafism poses to the consolidation of the democratic process, but very little is actually known about the way in which the Salafist ideology is differently interpreted and used in the areas of the country where it is taking hold. Belaid's assassination has not only heightened domestic tensions between seculars and Islamists, but brought once again Salafism to the fore in so far as mediatic analyses tend to focus on it to explain why the Tunisian revolution is being somehow betrayed. ${ }^{6}$ Through an examination of the less discussed aspects of the Tunisian transition, this article attempts to account for the emergence of Salafism and its arrival on the public scene, providing a picture of the differences that exist within it and highlighting new social and political practices that characterize it.

\footnotetext{
5) See for instance Anne Wolff and Raphael Levefre, "The demon or the demonized? Deconstructing 'salafism' in Tunisia," Open Democracy, June 5, 2012.

6) See for instance Peter Beaumont and Patrick Kingsley, "Violent tide of Salafism threatens the Arab Spring", The Observer, February 10 2013. Available at: http://www.guardian.co.uk/ world/2013/feb/og/violent-salafists-threaten-arab-spring-democracies
} 


\section{The Rise of Salafism}

One of the most interesting and surprising outcomes of the Arab Spring has been the forceful public emergence of Salafist movements across the region. In its modern meaning Salafism refers to "conservative Sunni Muslims who seek to apply literalist interpretations of scripture based on the example set by the Prophet and his companions."7 Salafist movements have been traditionally divided into two broad categories: scientific or scripturalist Salafists engaged in the promotion of individual behavioral change through dawa and jihadi Salafists engaged in violence to bring about an Islamic state where sharia would be imposed. Such categorization remains only partially valid today as Salafist movements across the region are displaying quite different modes of activism.

In Egypt, the vast majority of Salafists groups decided early on that they would take advantage of the electoral process to form a political coalition that did extremely well in the legislative elections, ${ }^{8}$ contravening in many ways one of the central tenets of scripturalist Salafism which forbids the creation of associations or parties. In Mali, Salafist groups benefited from the retreat of the central government in the northern regions of the country to strike an alliance with local separatist groups and create some sort of emirate governed through the imposition of strict sharia law. In doing so, these Salafists have imposed harsh social norms through violence. In Syria, Salafist armed groups are very active in the civil war against the government and are attracting an increasing number of foreign fighters. ${ }^{9}$ In Morocco, the vast majority of Salafists are still committed to political and social change through dawa and educational activities, although some of them are attempting to set up a political party. ${ }^{10}$ All this indicates, as Meijer had already suggested, that Salafism as a whole is a very complex phenomenon where different interpretations of the sacred texts give rise to different methods of political and social engagement. ${ }^{11}$ In addition, the specific

\footnotetext{
7) International Crisis Group, "Tentative Jihad: Syrian Fundamentalist Opposition," Middle East Report 131 (2012): 5 .

8) Stephane Lacroix, "Sheikhs and Politicians: Inside the New Egyptian Salafism," Brookings Institute, Policy Briefing June (2012): 1-12.

9) Elizabeth O'Bagy, "Jihad in Syria," Institute for the Study of War, Middle East Security Report 6 (2012): 1-42.

10) Sanaa Karim, "Party Politics for Morocco Salafis," Sada, October 2, 2012.

11) Roel Meijer (ed.), Global Salafism. Islam's New Religious Movement (London: Hurst and Company, 2009): 1-463.
} 
characteristics of very diverse national contexts create further opportunities and constraints for Salafist movements.

The case of Tunisia is particularly interesting for a number of reasons. First of all, Salafism never seemed to have a presence in the country. A significant number of Tunisians still contend that its emergence following the revolution is due to outside influences and that democratization has contributed to its creation, allowing foreign ideas and practices to reach the country very easily. As demonstrated elsewhere, this is not really the case and although important Salafist figures in Tunisia have 'cut their teeth' abroad, the movement as a whole finds its roots in the rise of Islamism of the late 1980 s and the protagonists of today are mainly a young generation of disenfranchised youth product of the later years of the Ben Ali dictatorship. ${ }^{12}$ Second, Salafist groups in Tunisia have the opportunity to operate in a very free, liberalized and plural political and social environment which, for the moment, does not really have any equal across the region. This opportunity further polarizes the debate within the Salafist movement about the best course of action to achieve its goals. Third, these groups have to contend with the fact that an Islamist party is in power. This means that while they are, to a degree, in conflict and competition with it, at the same time they have to recognize that they are not dealing with what they could label easily an 'impious' regime. ${ }^{13}$ Salafists are also aware that Ennahda could constitute a precious ally in the increasingly polarized struggle between Islamists and seculars that characterizes Tunisian politics. These specificities make the Tunisian case an exceptional one and can provide interesting and useful insights as to how Salafism operates and evolves.

While there is a tendency, particularly in the media, to treat the phenomenon of the rise of Salafism as a coherent and cohesive program of conservative revolutionary change usually associated with acts of violence and prevarication, this study demonstrates the heterogeneity of Tunisian Salafism and sheds some light on its inner workings and complexity in a situation of almost permanent flux, confirming earlier findings in the literature on Salafism.

12) Fabio Merone and Francesco Cavatorta, "The emergence of Salafism in Tunisia," Jadaliyya August 18 (2012). Available at: http://www.jadaliyya.com/pages/index/6934/the-emergenceof-salafism-in-tunisia

13) There has been in this sense an intense debate within the Salafist movement as to the degree and type of support that should be given to Ennahda with important figures arguing for an alliance of convenience with it to counter the secular camp. 
The first political actor that deserves to be analyzed when it comes to the Salafist movement is Jebah al-Islah (Reform Front). There are today other Salafist parties on the scene such as Asala, led by Ali Mouladi Jihadi, and Arrahma, led by Said Jaziri, but the Reform Front is more interesting in so far as its leaders can claim to have been the first modern Salafists active in Tunisia since the early 1980s. The creation of the Reform Front and its choice of participation in the current institutions of the state mark it out as exceptional because of the implicit acceptance of the democratic rules of the game despite sharia not being the legal framework for these democratic procedures and mechanisms. Its legalization in March 2012 indicates that there is a Salafist constituency interested in breaking with what can be called 'street politics' in order to institutionalize its political demands no matter how unappealing and radically conservative they might appear to the rest of society. As the party also makes clear, their primary objective is to 'catch' the Salafist support that is clearly present in wider society and turn it into electoral and political capital to be used to attain the most significant political goal the party has: the application of sharia law in Tunisia. As the party leader Mohammed Khouja told the authors in an interview held on October 24, 2012 at the party's headquarters in Tunis, 'our ambition is to unify the Salafist front.' Another leading member of the bureau executive of Jebah al-Islah, Rafik Aouni interviewed by the authors on October 22, 2012 in Tunis, spoke for instance of the contacts and exchanges they have with the Egyptian Nour regarding their political experience as political parties involved in the institutions of the state.

In reality, this perceived institutionalization of Salafism is nothing novel for the members and leaders of this party in so far as it represents the continuation of what they had already done in the 1980 os when they broke from the Mouvement Tendence Islamique (MTI) - Ennahda's precursor - to form the Tunisian Islamic Front. Thus, in many ways, the dilemma of whether Salafists should create a political party even in apparent contradiction with the ideological tenets of orthodox Salafism had been solved three decades ago for this older generation of Salafists because the theoretical and ideological debate over direct participation in politics through a party did not really exist at the time. As Mohammed Khouja argued 'at the time [1970s and 1980s], the choice between dawa or politics was not much part of the theoretical debate on how Muslims should be involved in the betterment of their society in the sense that it was for us obviously a matter of doing both although we had differences regarding the degree to which the group should privilege one or the other.' Thus, in the case of Jebah al-Islah and the 
other legal Salafist parties, we can talk about re-institutionalization because forming a political party was for this generation not particularly controversial. This is further demonstrated when one looks at the relationship of the Jebah al-Islah with Ennahda. The major divergence between the two parties does not evolve on the choice of doing politics and not even on the pluralism that the political system should display, but has to do with the vision of society that the two movements have. Contrary to Ennahda, Jebah al-Islah is thoroughly committed to the application of sharia law as a foundational source of legislation with fundamentalist and orthodox canons proper of Salafism. It is very difficult to gauge exactly the popular support of Jebah al-Islah in a country in transition and where there is a considerable degree of volatility, but according to a poll published in September 2012 the party does not figure as having any real electoral support. This is due to the fact that Jebah al-Islah is a party for Salafists of a much older generation despite having, according to the leaders, the important support of leading Salafist sheikhs such as Kamel Marzouki, Bachir Ben Hassen, Hassin Shaouat and Hatem Bou Soma. ${ }^{14}$ These figures however prefer to remain involved in education activities and more broadly in civil society activism rather than becoming political public figures and openly endorse the party. In addition sheikhs like Bachir Ben Hassen are labeled 'Salafi-lite' and their activism does not seem to have much traction with radical jihadi circles. Irrespective of the genuine degree of support that such sheikhs might give the party, it is important to note that they do have however a common objective: the moderation of the young Salafist radicals imbued with jihadism - not necessarily defined as armed struggle rather as internal striving - in order to de-radicalize society and, at the same time, indicate a political outlet in institutional politics. What is clear is that the legal parties and the Salafi-lite sheikhs attempt to counter the violent tendencies that exist within jihadi Salafism and that have led young Salafists to be involved in numerous incidents such as the attacks on the US embassy, the destruction of holy sites associated with the 'wrong' practice of Islam and rioting with the police.

In any case, it is young Salafist radicals, whether violent or not, that better represent the emergence of Salafism in Tunisia and it is this cohort that is one of the most significant political and social protagonists emerging from Tunisian transition. Broadly speaking, it largely rejects institutional

14) These four sheikhs founded the private university 'Imam Malek of Sharia Sciences' in the autumn of 2012 located in Tunis. 
politics because it does not believe that politics within plural institutions can deliver the ethical goods they crave. As Meijer argues, 'because its emphasis is on doctrinal purity and not politics, Salafism ... has been able to empower individuals by providing a universal model of truth and social actions.' Thus, individual empowerment becomes central to the detriment of institutional political engagement. The sociological composition of these Salafist radicals is largely that of the mouhammishin - the disenfranchised - of Tunisian society. This term is quite useful to understand the phenomenon of this radicalism in so far as it is used in a derogatory sense in those political and social circles that are participating to the construction of new institutions. The sense that the liberal-democratic order being built in Tunisia is the work of two different social blocs (a conservative religious bourgeoisie and a nationalist modernizing one), which excludes a priori the more radical political demands of the poorer classes of society, permeates the activism of the Salafists. The usefulness of the terminology of the muhammishin is also that they were the protagonists of the revolutionary uprising and met the violence of the security forces with violence of their own reinforcing through their actions the revolutionary drive of the rest of society, as indicated in Amin Allal's work as well. ${ }^{15}$ These young men, as they are overwhelmingly men, are generally poorly educated, come from lower classes and they have very rarely opportunities to enter the job market because they lack the necessary skills to compete. In fact, they represent the dark side of the development model that Ben Ali offered. They are the ones who attempted to leave the country in order to reach the northern bank of the Mediterranean illegally - incidentally it is something that continues to this day - and often displayed a considerable degree of social violence in very specific and confined contexts such as football stadiums. ${ }^{16}$ This cohort has been left out not only from the material benefits of the 'Tunisian economic miracle', but also from the cultural and social practices associated to the modernizing efforts and reforms of the previous regimes whereby any regime-led discussion of modernity and secularism was not even contemplated and reflected upon. It simply did not reach this sector of society in any meaningful way. On the contrary, their values of references

15) Amin Allal, "Avant on tenait le mur, maintenant on tient le quartier," Politique Africaine, $121(2011): 53-67$.

16) Laryssa Chomiak and John Entelis, "Contesting Order in Tunisia. Crafting political identity," in Civil Society Activism under Authoritarian Rule, ed. Francesco Cavatorta (London: Routledge, 2012), 73-93. 
as well as the symbols they use is rife with forms of simplistic religious representation, which is an edgier re-elaboration of what they are daily exposed to in their family environment and in their immediate neighborhood, the real extent of their socialization outside the home. Obviously, the social composition of the Salafist movement is not restricted to the disenfranchised because there is also the important presence of 'learned' older sheikhs who have a different background. In addition the movement has an interest in being portrayed and projecting an image of defending the cause of the downtrodden. However, embracing Salafism is about building a new individual and collective religious identity that is attractive to many young disenfranchised people because it provides not only a clear framework within which they understand their condition, but, more importantly, allows them to improve their social standing in so far as they are now part, as Salafists, of the selected few to whom the truth has been revealed. When the dictatorship falls and new spaces of post-revolutionary identification are permitted to exist out in the open in a rapid liberalizing and pluralizing society, many of them quite spontaneously embrace the more radical form of Salafism with jihadi inclinations because this allows them to express their radicalism through the permissible language of religion. This type of Salafism, which, once again, needs not to embrace armed violence because it can be also practiced as militant individual engagement to be a better Muslim and strive to convince others of the 'right path', also provides a political dimension that allows the mouhammishin to question the way in which the new Tunisian political authority is being constructed because, just as the previous one, it marginalizes them and becomes therefore unjust. It should be anticipated at this stage that the demands of the Salafist movement are however not linked to specific economic grievances in any class-based sense and therefore we cannot refer to the classic concept of class to frame it. Salafism is appealing to the disenfranchised not because of the potential material benefits that engagement with the movement might deliver once political power is obtained. Far from it, it is appealing because 'Salafism transforms the humiliated, the downtrodden, disgruntled young people, the discriminated migrant, or the politically repressed into a chosen sect (al-firqa al-najiya) that immediately gains access to the Truth.'17 It is this message and practice of what can be considered moral and

17) Roel Meijer, "Introduction" in Global Salafism. Islam's New Religious Movement, ed. Roel Mejer (London: Hurst and Company, 2009), 1-32. 
intellectual superiority that empowers individuals, mobilizing them as a collective entity to convince others of the religious authenticity of the path they chose. As Monica Marks aptly put it, 'for young Salafis, many of whom feel unrepresented by Ennahda, economically disenfranchised, and increasingly shunted aside by the elitism of Tunisian party politics, the promise and purity of Islam remain immensely inspirational.'18 In addition to this, the return to the perceived purity of the original religious message and practice of Islam offers two significant instruments. First, it allows them to find points of reference that explain their marginal socio-economic condition and a map to get out of it in a world they cannot otherwise make sense of due to the clash between Western modernity and tradition they find themselves trapped in their own society. Embracing the authentic message of the sacred text is the only way out of marginality. Second, it provides them with a tool to criticize their elders who are accused of subscribing to a religiosity that is both repetitive and unfulfilling and therefore unable to capture and understand the universal significance of Islam and of the prophet's mission. After all their 'fathers' had willingly or unwillingly accepted the corrupt, authoritarian and impious government of Ben Ali while they succeeded in overthrowing it. As Haykel highlights in his study on Salafism, 'it is striking how relatively easy it is to become an authority figure among the Salafis,'19 which allows young people to therefore challenge older and more learned scholars and figures if they do not embrace the authenticity of the religious message. This aspect of Salafism is quite helpful to those young people that are still in a revolutionary frame of mind where traditional relationships can and should be subverted. The absence of respect within Salafist circles for prominent figures of Tunisian Islamism such as Abdelfattah Mourou is a testimony to that. In part therefore, the absence of appeal for the message of Jebah al-Islah can be thus linked to this generational fracture and suggests that there are other political actors within salafism more capable of conveying the instances of the mouhammishin. Leading Salafists have no qualms admitting that they belong to and they seek the support of this social category of disenfranchised; in fact they find pride in it. Whereas other political forces including Ennahda and

18) Monica Marks, "Who are Tunisia's Salafis?", Foreign Policy, The Middle East Channel, September 28, 2012. Available at: http://mideast.foreignpolicy.com/posts/2012/o9/28/who _are_tunisia_s_salafis?wp_login_redirect $=0$

19) Bernard Haykel, "On the nature of Salafi thought and action" in Global Salafism. Islam's New Religious Movement, ed. Roel Mejer (London: Hurst and Company, 2009), 33-57. 
sectors of scientific Salafism use the representation of such a social category to discredit them, the jihadi Salafists in particular consider this class as the vehicle for a process of genuine indigenous Islamic re-generation in Tunisia and the point of departure of their mission of dawa. The dawa officer of the Salafist movement Ansar a-Sharia, Hassan Briek, jailed for his perceived role in the attack on the US embassy in September 2012 and released in January 2013, reveals with pride in an interview with the authors held on September 222012 in Yasminette, that many of the young people now active in the movement were recruited in jail during the Ben Ali era when they were serving sentences for non-political crimes. This highlights the connection between the marginalized youth falling into a life of crime and their subsequent 'conversion' to Salafism through dawa in prison. This is a point of pride for the movement rather than shame because it demonstrates the power of the religious message in redeeming lives. In addition, the same Hassan Briek talks about the large following that the movement has in difficult-read poorer-areas and neighborhoods such as Ettadhamen, al-Omrana al-ala, al-Khadra and Ibn Khaldoun in Tunis, Menzel Bourghiba and Sejenene in the province of Bizerte and Sidi Bouzid. Briek is happy to claim the success of the process of politicization of a social group that encountered and still encounters considerable discrimination and contempt from the rest of society. It is very difficult to establish with any certainty the number of activists and supporters that come from a disenfranchised background because of the embryonic organizational structures the movement has (Salafist activities usually take place at the local mosque level) and because of the reluctance to divulge what might be seen as sensitive information. In any case, field observation indicates that most of the Salafist activism occurs in what might be labeled problematic poorer areas in urban centers. The politicization of the mouhammishin into Salafism exposes some of the difficulties of a transition to democracy that seems to concern only higher social classes, busy finding an institutional democratic compromise that is not perceived to be able to radically change social relations in Tunisia because it is fundamentally a bourgeois pact within which, inevitably, some form of unbelief, according to Salafists, will be enshrined in so far as the secular sector of society has to be accommodated. Largely confirming the fracture and absence of communication within Tunisian society is the fact that while the Constitutional Assembly keeps working on the new text and the traditional politicians are busy arguing, very few notice the growth of the Salafist phenomenon and even fewer analyze it and understand it, limiting themselves to condemn the 
most visible and violent demonstrations of its presence. The relevant role of the concept of class might seem outdated, but it is helpful in framing the way in which political struggles occur in the Arab world more generally, ${ }^{20}$ but in Tunisia in particular because it allows a better understanding both the phenomenon of Salafism itself and the fear it instills in the other sectors of society, although the Salafist movement does not frame its activism in terms of class and its ranks are the lumpenproletariat. ${ }^{21}$

The identification of the social group that radical Salafism largely draws from should not however lead to the assumption that there is a unified structured movement that is capable of monopolizing its representation nor that the demands of such movement build on economic grievances. Thus, a movement like Ansar a-Sharia, despite its importance and its undoubted primacy, should not be conflated with the whole spectrum of radical jihadi Salafism, which can be better defined as a movement or tendency with unitary ideological pillars, religious and social references and political goals without yet a unified organisational structure that can speak for the whole camp.

\section{A Movement in Search of an Organisation?}

The overwhelming focus of Tunisian politicians, the media and the international community on Salafists involved in violent demonstrations or in disruptive behavior usually leads to calls from the secular sector of society and many within Ennahda for a crackdown on Salafist activism.For repression to work however, it presupposes that there is a tightly organized structured movement within Salafism that can be easily targeted. This is not yet the case and this focus on the violence that Salafists at times display on the public scene should not obscure the fact that there is a daily practice of Salafism where there is no violence and, in addition, where differences over the direction of the movement forcefully emerge in line with the traditional divisions that plagued Salafism since its inception.

20) See for instance for the Egyptian case Hazem Kandil, "Why did the Egyptian Middle Class March to Tahrir Square?," Mediterranean Politics 17 (2012): 197-215.

21) We are grateful to Yahia Zoubir for bringing this point to our attention and for suggesting a parallel with the failed Algerian transition in the early 1990s and the role of the Algerian lumpenproletariat in swelling the ranks of the Front Islamique du Salut. 
The daily practices and social activism of Salafism can be seen at work in the areas and neighborhoods mentioned earlier as a form of socialization that involves a youth that does not feel represented by the political system and prefers the clarity of the Salafist message because it allows them to take control of their lives and still live in a revolutionary climate because through the authenticity of the message they espouse they are building a new society from the bottom-up. It is in these very specific contexts, and following the radicalization that both precedes and follows the revolution, that we see the emergence of a phenomenon that can be defined as 'sheikh-ism.' This is the arrival on the scene of a number of young sheikhs whose youth shocks and amazes society at large where an older generation, from politics to business to religious scholarship usually dominates. As mentioned earlier, the revolutionary nature of Salafism is not necessarily about subverting a specific political order because of the 'quietist' tendencies that exist within the movement at large. Its revolutionary nature is that it provides clear doctrinal instruments that allow young people to be empowered and feel morally superior allowing them to subvert generational hierarchies. These young sheikhs found Salafism in two different manners. First, radicalization and religious awareness occurred in Ben Ali's prisons during the period 2005-2011. Second, they became Salafist in the immediate aftermath of the revolution through a very rapid process of politicization forged in the clashes with the security forces and legitimized by the participation of the mouhammishin for the first time as social subjects in the success of the uprising. These young sheikhs become the transmission belts of knowledge and activism between the better known older Salafist sheikhs, who excel in the religious sciences or have acquired legitimacy because of their personal participation in international jihadi activities such as the war in Iraq, and the ordinary activists in their neighborhood of reference over which they exercise a degree of influence. What we have is not though an organized network that is structured around a formalized hierarchy, yet, but a looser type of an ever extending network based on personal informal contacts that is favored by the 'preaching tours' that the better known sheikhs undertake throughout the country to lecture at different mosques. Some of these sheikhs do not simply lecture, but also offer longer courses on a specific topic or author and award students a form of accreditation of knowledge on religious matters. These lecturing tours go hand in hand with the creation of religious schools across the country. Non-governmental associations set up these schools and are in some ways the continuation of a phenomenon that had appeared in the late Ben Ali period when a number 
of Quranic schools were opened in order to promote the correct reading of the Quran with the proviso that they refrain from engaging in political issues. ${ }^{22}$

All these activities contribute almost inevitably to a process of structuration of the Salafist movement, but at the same time expose the significant differences that exist within it regarding the desirability and the extent of such structuration as well as divergences about leadership. Thus, with the expansion of the education dawa through the lectures and speaking tours and the sharing of symbolism and ideological convergence, there is the spontaneous emergence of three loose hierarchical levels: the famous religiously knowledgeable sheikhs who are the theoretical and ideological points of reference; the neighborhood sheikhs that function as the intermediaries connecting the leaders of the movement to the popular base and then what can be described tentatively as ordinary activists who remain the more volatile part of the movement and do not necessarily follow in any meaningful way the directives and instructions coming from above precisely because a traditional organizational structure with its rules and procedures is still non-existent. In addition, the generational differences come into play. Older sheikhs' views are not necessarily accepted in their entirety and when they are perceived to be wishing to take over the whole jihadi movement or speak in its name, the younger generation fails to accept it. After the attack on the US Embassy in Tunis in September $2012 \mathrm{a}$ number of jihadi sheikhs appealed for calm and encouraged young activists to go back home and refrain from undertaking such acts in the future. Some of the older sheikhs had met President Marzouki and issues statements appealing to calm after the meeting. A similar scenario occurred again during the rioting between Salafists and the police in Douar Hicher in October 2012. In response to this, according to a young sheikh, the internal debate intensified. In an interview with the authors on January 22, 2013 he stated 'the youth of the movement was against it [the meeting at the presidential palace]. It was a mistake, and we have no qualms to say it before our sheikhs. If the state wants to open a dialogue it has to come to us and not the opposite.' This inter-generational mistrust even with the movement compounds the two most significant issues for the Salafist movement: how to deal with an embryonic structure that is still quite loose and whether it is desirable to strengthen it.

22) Rikke Hostrup Haugbølle and Francesco Cavatorta, "Beyond Ghannouchi. Islamism and Social Change in Tunisia," Middle East Report 262 (2012): 20-25. 
It is at this juncture that the complexity of Tunisian Salafismis demonstrated because we have the emergence of three camps that while agreeing on the fundamental ideological and doctrinal points of creating an Islamic state ruled by a strict interpretation of sharia law that would purge Tunisia of its Western-style modernity and of its religious reformism, are divided over the best way to achieve this goal. In addition, the movement and its ideological leaders in particular have to contend with two important aspects that affect their thinking. First there is the realization that the Salafist movement is growing quite rapidly and to a large extent independently from clear organizational structures, as more and more young individuals make the choice of personal religious rediscovery according to Salafist canons. Second, there is also the 'fear' that too many un-controlled acts of violence on the part of what the rest of society sees as Salafist youth is damaging the image of Salafism as whole, equating it with violence and inviting repression. All of this leads to the opening up of an intense debate over structure and organization. To begin with there are two rather clear camps: the one favorable to the creation of clear and formal structures and the one resolutely opposed to it for both ideological/doctrinal and strategic reasons. A third camp might also slowly be emerging that is attempting to reconcile the two positions. The first camp is well represented by Abu Ayadh, the architect and recognized leader of Ansar a-Sharia. The group was founded officially in May 2012 although it had been operating already for almost year by then. The opposite camp finds in the works and activities of sheik Khatib Idrissi its point of reference. Idrissi is considered the spiritual father of modern radical Tunisian Salafism. The third emerging camp can be seen in the attitude of Abu Abdallah Attunsi, another important and respected sheikh representing the middle-ground. When asked about his personal position on this debate in an interview on October 8, 2012 in Sidi Bouzid with the authors he replied that he preferred to remain in the middle and operate for a synthesis of the two options.

The intensity of the debate over the creation of formal organizational structures is explained by the fact that the principle of creating an organization is intrinsically in conflict with the 'spirit' of Salafism. For instance, scientific Salafists abhor all references and connotations that can lead one to identify the activism of Salafists with specific organizations. This is because it is in contradiction with the absolute principle of tawhid (unity), which is the theoretical foundation of Salafist thinking. The subscription to this principle of unity is shared across all Salafist currents and is the ideological foundation for Salafist orthodoxy. In many ways it crucially opposes 
the principle of hizbiyya, which the term hizb as political party is derived from, because it is linked to the concept of juz'ia - partiality - considered to be the first step towards the problematic divisions within the community of believers and therefore the ultimate negation of the principle of unity. It is a form of shirk (associationism). All this would indicate that structuring Salafism in order for it to take part in a process where these divisions within the umma are institutionalized should not occur because genuine Salafists should simply work within society to make these divisions disappear, justifying therefore the rejectionist approach of the second camp. However in very specific cases, as Abu Kattada makes it clear in the official organ of Ansar a-Sharia al-Wa'ad, ${ }^{23}$ when for historical contingencies the umma finds itself in a position of weakness because under threat for instance from secular modernity or impious imperialism, the necessity to save it allows for the organization of a cohesive and formal group that is charged with leading the umma to 'safety.'

This notion of the vanguard, which is an implicit reference to the work of Sayyid Qutb, therefore appears to justify the position of those like Abu Ayadh who emphasizes the present necessity for a formal organization. The Tunisian Salafist movement, and Salafism more generally, therefore display a rather profound fracture between those who are influenced by Qutb's thinking and by implication that of the Muslim Brothers - keen on political participation through formally organized groups- and those who can be labeled as 'fundamentally Salafists' anchored to the hyper-orthodox concept of tawhid. In practice this debate is translated in everyday activities with tentative steps towards a form of organizational institutionalization such as the one that Ansar a-Sharia represents and a pulling-back effect on the part of those who, while sharing Ansar a-Sharia's objectives and ideological commitment, are still not convinced that a jamaa is yet necessary. For instance there are many young people who utilize the symbols of Ansar $a$-Sharia and share the political project of the group, but, at the same time, come close to negating its very existence because the local sheikhs of reference do not share the theoretical approach of Abu Ayadh and are therefore reluctant to be seen condoning the creation of a formal structure. As the young Salafist B. in an interview with the authors on September 25, 2012 in Tunis affirms 'we are all brothers, and every single one of us is responsible for himself' suggesting that there is no need to belong to any organization

23) Abu Kattada, "Between two methodologies," al-Wa'ad No. 3, August (2012): 18-19. 
in order to be the 'good Muslim' that society requires you to be. More importantly it is not necessary to be a card-carrying member of a Salafist group because it is your personal example that is transformative of society. This partly explains the reason why it is so difficult to give Salafism a recognizable and recognized face that represents the whole movement.

The 'US embassy crisis' of September 2012 highlights well the problems arising from any attempt to clearly identify and categorize Tunisian Salafism. Faced with the extremely worrying and negative consequences of the attack on the US embassy, the ruling coalition, under pressure both domestically and internationally to crack down on Salafism, targeted the leadership of Ansar a-Sharia. This led to arrest and imprisonment of many of its leading members, but not Abu Ayadh who became a fugitive. The repression of Ansar a-Sharia however brings to light the complexity of Salafism discussed above because the crackdown does not stop the growth of the movement in so far as it is unable to come to terms with the fact that Ansar a-Sharia does not represent the entire spectrum of Salafism. There are three different ways in which this complexity emerges on the public scene. First, we have the criticism of Ansar a-Sharia and Abu Ayadh coming from within the movement itself, specifically from that sector that never agreed with his choice of formal structuration precisely because it would invite, rather needlessly, repression rendering therefore the educational dawa potentially more difficult. Second, members of Ansar a-Sharia such as Hassan Briek questioned the validity of the crackdown in its political and strategic premises. For him, implicitly, targeting Ansar a-Sharia for repression is a mistake because he sees the movement as a positive development in so far as it strives to give a 'proper' formal coordination and structuration to what is a popular Salafism in a state of flux, avoiding therefore its fusion in society as an anti-systemic force difficult to pin down. For Briek, Ansar a-Sharia is actually rendering a service to the ongoing process of institutionalization. Third, the lack of efficacy of the repressive campaign against Ansar a-Sharia in halting Salafist activism made the ruling coalition realize that the true nature of it is found in the movement and not in a movement. Thus, the state authorities attempted to reach the sector of un-structured Salafism through a dialogue with the leading figure in the second camp, sheikh Khatib Idrissi. On October 112012 the President of the Republic met officially with representatives of the salafist movement (among them, Khamis al-Majri, Mohammad Manif, Abu Abdallah a-Tunisi) nominated by a council of sheikhs headed by Idrissi himself. Thus, paradoxically, the ones who were against the creation of organisational 
structures that could institutionalise Salafism found themselves having to create a structure, in this case the council of sheikhs, in order to 'negotiate' with representatives of the state to de-limit the space of activism and the boundaries of the permissible on the public scene. This indicates that even in the second camp the necessity of having at the very least a coordinating instance-tansiq - is present. It is this realization that favors the emergence of the third camp, attempting to reconcile two approaches that are theoretically in conflict, but that have to find some sort of compromise because of the liberal and democratic reality within which Salafism itself is operating. This reality requires a degree of institutionalized representation for negotiating purposes.

\section{Elements for Reflection}

This examination of the emergence and complexity of Tunisian Salafism outside the alarmist framework through which the phenomenon is often presented and discussed in public debates both inside and outside the country offers the possibility to link it to wider theoretical issues that are of importance for the understanding of processes of regime change.

First, any analysis of Salafism in Tunisia cannot exclude the class element that characterizes it. While the category of social class of Marxist inspiration might not be any longer appropriate to understand political phenomena in established democracies and advanced states, this is not necessarily the case in developing societies going through profound economic and political changes. Salafism in Tunisia is linked to the political and social expression of a social group of largely disenfranchised youth that perceives, rightly or wrongly, the construction of a new political system as the renovation of a mechanism that, while no longer authoritarian, still excludes them from the enjoyment of material and ethical benefits they feel entitled to for having played a crucial role in the defeat of the Ben Ali regime. While this social group lacks the political self-consciousness of being a class and does not necessarily display economic grievances, the bulk of the recruits and activists have a distinct sociological profile. A very significant part of Tunisian society did not participate in the historic 2011 elections because it did not see how a new political system would change their everyday conditions and a sector of this 'non-participative' society identifies the current political and social blocs in the Constitutional Assembly with a political conservativism destined to replicate the existing class structures 
and preventing the coming of a genuine Islamic state where these would disappear. This class discourse is obviously not thought out in Salafist circles, but it should be noted in so far as the left in Tunisia could also become the beneficiary of the disillusionment of the disenfranchised if it were to campaign seriously in poorer urban areas. Thus, the problem is not necessarily about the redistribution of material goods, although this plays a role, but is more intensely about ethical demands that Salafists see anchored in religion and, more specifically, in the mythical application of sharia law that by itself would solve all problems. The refusal in particular of Ennahda to subscribe to the application of sharia in a fundamentalist manner is perceived to be an insult to Islam itself and therefore Salafists are unwilling to become involved in the construction of a political system that leads to an unjust society. The marginalization of this social class from the wider process of transition to democracy recalls an older debate about the way in which a democratic system can be built when it has to accommodate the socio-economic demands coming from the disenfranchised sectors of society. ${ }^{24}$ In order to build a liberal-democratic system these demands should be postponed with the preference for the establishment of clear procedural rules to govern the country. While this might indeed generate better functioning institutions, it impedes the allegiance to the new system of vast sectors of the population as their demands, so they are told, are going to be dealt only at a later stage when the new institutions have proven their strength and durability. This strategy carries risks in the longer term because meeting the socio-economic and ethical/moral demands of the disenfranchised might not occur in the future, leading to profound imbalances. Tunisia is not there yet, but the confrontation with the Salafist movement might be an indication of how different social blocs interpret and more importantly live in their everyday practices the success of the revolution. What is important to highlight is that not all the disenfranchised find in Salafism the answers they are looking for. On the one hand, there are small socialist/communist formations that attempt to mobilize it, although with little success. On the other, there is a degree of apathy towards anything that is even remotely linked to politics or strict religious behavior that impedes the 'enjoyment' of new found freedoms.

Second, the Salafist movement finds itself in a predicament with respect to the wider environment in which it operates. All Salafists are clearly

24) Giuseppe Di Palma, To Craft Democracies (Los Angeles: University of California Press, 1990). 
opposed to any form of democracy that is outside the bounds of sharia law. In this sense they approve of democratic mechanisms of representation as long as the legislative outcomes are not in contradiction with sharia. This is however not the case at the moment, in so far as both the draft Constitution and ordinary legislation do not codify sharia in any meaningful way and, in addition, it is possible for decisions that go against sharia to be adopted as public policy. All this is exemplified in the answer that Briek gave to the question of how Ansar a - Sharia thinks about democracy:

we do not believe in democracy, although this does not mean that we are against the idea of elections or consultations to elect the representatives of the community. The point is that until we live in a society where there are secular people or there are those who do not apply sharia law, we cannot conceive of the fact that in the name of majority rule a contravention of divine norms could be permissible. Within the framework of sharia law there is no reason why the community could not choose [through elections] its own representatives.

However, there is a clear realization that the free plural environment that they theoretically reject allows them to operate with little restraint either institutionally, if they choose that option, or in wider society through educational dawa. Despite the different ideological and theoretical approaches to organizational matters that divide the movement, all agree that at the moment the situation is rather favorable in so far as the degree of autonomy they enjoy is sufficiently strong to allow them to grow. It also means that in order to be able to continue to do so in a relatively repression-free environment they have to come to terms with two factors. First, the recourse to armed violence to impose their vision of society has to be out of the question because this would simply invite a conflict with the authorities and the other sectors of society that would ultimately undermine their ability to further penetrate society. This realist attitude with respect to the surrounding environment has led a prominent Salafist figure such as $\mathrm{Abu}$ Ayadh to repeat over and over that 'Tunisia is dawa-land' and not an arena of open conflict between belief and unbelief that would justify resorting to violence. This message is shared in internal debates among the different strands of salafism, including the sheikhs who publicly endorse Tunisia as dawa-land. This does not mean that there have not been and there are no violent incidents involving Salafists. These have occurred on numerous occasions. However such violence is not widespread nor systematic precisely because the leadership and many young sheikhs are not keen on it for both ideological and strategic reasons. Second, there is the recognition that 
some form of coordination or structure is needed to negotiate spaces of activism with the state as outlined earlier.

Finally, it is important to acknowledge that the rise of Salafism is progressively and paradoxically empowering those sectors of society militantly opposed to it. While under Ben Ali there was a sort of delegation of the battle against radical Islamism to the security services on the part of liberals and seculars, in the new Tunisia, where this is no longer possible, this sector of society has to find the strength and mobilizational capacity within itself to stand the challenge of what they refer to as obscurantisme. ${ }^{25}$ The appearance of such strong conflicts over radically diverging views of society in public can be in some ways cathartic for the country as whole because it is forced to be confronted with political projects that while antithetical still find a degree of common ground in the nominal subscription to the recognition of the pluralism present in Tunisian society. In this context it is up to the political system and the elected representatives to build institutions that are capable and sufficiently strong to manage such social conflict and find the balance for the creation of a 'pact of co-existence.' The success of the Tunisian transition and therefore the role that Salafism will ultimately play depends on the strength of this pact and events such as the assassination of Belaid seem to unfortunately point in the opposite direction.

\section{Conclusion}

This article does not question the importance of examining the institutional and political games that take place at state level with their emphasis on the workings of the Constitutional assembly, the political parties and the reform process of the institutions of the state. However it is also important to analyze what occurs 'below the radar' in wider society without falling into the dual traps of surprise and alarmism. The Salafist phenomenon in Tunisia is a relevant aspect of the changes that have taken place in the country over the longue durée and a closer look at its complexity is necessary to highlight both the constraints and opportunities that weigh on the whole process of transition.

25) Nadia Marzouki, "Four keys to understand Tunisian politics after the elections," Focus article, Observatory of Euro-Mediterranean Policies 11 (2011): 1-4. 
F. Merone and F. Cavatorta /

Salafism in Tunisia is in a state of flux, rife with internal contradictions and characterized by intense debates over the direction it should take in the future, but it also provides an opportunity for Tunisian society to engage in a rhetorical confrontation with a movement that both rejects and benefits from the plural political and social system it operates in. 
